\title{
THE PHYTOREMEDIATION POTENTIAL OF LOTUS: DEGRADATION BOD AND COD LIQUID COFFEE WASTE
}

\author{
Maria Ulfah ${ }^{1)}$ Dian Asmaranty ${ }^{2)}$ Atip Nurwahyunani ${ }^{3)}$ \\ Universitas PGRI Semarang \\ mariaulfah@upgris.ac.id
}

\begin{abstract}
Liquid coffee waste has the main component in the form of organic matter which is very resistant to increasing pollutant loads. Preliminary research results show that the level of pollution exceeds the quality standard with the test results of $23 \mathrm{ppm}$ BOD and $72 \mathrm{ppm}$ COD, so we need a way to prevent pollution. One way that can be used is the phytoremediation method by utilizing plants as pollutant degrading agents. The purpose of this research was to determine the effectiveness of lotus in degradation of BOD and COD of liquid coffee waste. The research method used an experimental method with a Completely Randomized Design consisting of four variations of lotus biomass $0 \mathrm{~g}, 25 \mathrm{~g}, 50 \mathrm{~g}$, and $75 \mathrm{~g}$ with three replications within 6 days. The results showed a degradation of BOD and COD levels varied. The most effective treatment for lotus phytoremediation on day 3 was $\mathrm{P} 3$ with a biomass of $75 \mathrm{~g}$ resulting in a degradation of BOD and COD reaching $72 \%$ and $71 \%$ which met the PP RI No. 82/2001 with a maximum limit of 3 ppm BOD and $25 \mathrm{ppm}$ COD. The results of the homogeneity of variance test showed that the four treatments had homogeneous variance and analysis of variance showed that $\mathrm{F}$ count $>\mathrm{F}$ table $5 \%$ (4.07) and > F table 1\% (7.59). These results indicate that lotus is effectively used as phytoremediation of liquid coffee waste. The conclusion of this research is that lotus is effective in BOD and COD degradation of liquid coffee waste.
\end{abstract}

Keywords: BOD, COD, Phytoremediation, Liquid Coffee Waste, Lotus.

\section{INTRODUCTION}

The development of the coffee industry in Indonesia has a positive impact, including contributing to job creation, but another side that the coffee industry has the potential to cause environmental pollution. One of the consequences of the growing development of coffee processing plants is the emergence of problems related to the liquid waste produced (Sariadi, 2011). Liquid coffee waste has the characteristics of a thick color, pungent smell, high Biological Oxygen Demand (BOD) and Chemical Oxygen Demand (COD) (Rukmawati, 2015). In addition, liquid coffee waste contains organic materials in the form of carbohydrates, proteins, and fats that make up living organisms and other compounds needed by humans. Organic matter mainly consists of elements $\mathrm{C}, \mathrm{H}, \mathrm{O}$, or added other elements, namely $\mathrm{N}, \mathrm{S}, \mathrm{P}$, and Fe (Manik, 2016).

Based on a preliminary study on the BOD and COD value in liquid coffee waste in the laboratory, the results obtained were $23 \mathrm{ppm}$ BOD value and 72 ppm COD value. Based on Government Regulation Republic of Indonesia No. 82/2001 concerning Water Quality Management and Water Pollution Control, the levels of BOD and COD are above the established quality standards, which are $3 \mathrm{ppm}$ and $25 \mathrm{ppm}$, respectively.

Biological Oxygen Demand (BOD) is the amount of oxygen needed by microorganisms in water to decompose organic matter. The BOD value can be used to estimate the amount of organic matter in wastewater that can be oxidized and will be decomposed by microorganisms through biological processes (Atima, 2015). While the COD is the amount of oxygen required to chemically oxidize organic materials, both of which can be degraded biologically and which is difficult to degrade biologically into $\mathrm{CO}_{2}$ and $\mathrm{H}_{2} \mathrm{O}$ (ATIMA, 2015). The high levels of BOD and COD in the waters cause an oxygen deficit so that it interferes with the life of aquatic organisms, one of which affects the existence, growth, and survival of fish (Khaer \& Nursyafitri, 2019).

One of the waste treatment methods to reduce organic matter is the 
phytoremediation method. Phytoremediation is defined as a system where certain plants cooperate with microorganisms in the media (soil, coral, water) to convert contaminants (pollutants) into less or harmless. These plants can filter, adsorb organic particles and adsorb metal ions contained in wastewater through plant roots which may be used as remediators of water contaminated with sewage (Raras et al., 2015).

Lotus plant is a type of aquatic plant that has the potential as a phytoremediator to reduce environmental pollution. Lotus is able to absorb nutrients and water-soluble contaminants through its roots. The morphology of the lotus root which is very dense and long can expand the area of water phytoremediation (Rukmi, 2014). Based on the results of existing research, lotus plants can be used to reduce ammonia levels in domestic waste by $84 \%$ within 6 days (Andyanto et al., 2019).

The coffee processing industry does not yet have a sewage treatment system and the condition of the liquid coffee waste produced contains organic matter that is able to increase BOD and COD value. So that efforts are needed to reduce BOD and COD value in liquid coffee waste. Therefore, it is necessary to conduct research to examine the effectiveness of lotus phytoremediation on reducing $B O D$ and COD value in liquid coffee waste.

\section{RESEARCH METHOD}

The materials used in the study were jerry cans, tubs treatment, thermometers, $\mathrm{pH}$ meters, and DO meters. This research used experimental research with a Completely Randomized Design with 4 variations of lotus biomass, namely $0 \mathrm{~g}, 25 \mathrm{~g}, 50 \mathrm{~g}$, and 75 g. Liquid coffee waste is taken by purposive sampling. The repetition was done 3 times. The number of samples required is 9 treatment samples and 3 control samples. The coffee liquid waste required for one tank treatment is $20 \mathrm{~L}$. The lotus plant is acclimatized for one week in order to adapt to the new environment (Mahyatun et al., 2014). Then the plants were contacted with wastewater for 6 days from the time the lotus plant was put in the experimental tank.
Measurements of temperature, $\mathrm{pH}$, and dissolved oxygen levels were carried out at the beginning before the experiment and at the time of treatment. The effectiveness of reducing $\mathrm{BOD}$ and $\mathrm{COD}$ value was calculated from the percentage difference between the initial levels and the final levels after the experiment. Analysis of the data used in this study is using Analysis of Variance (ANOVA) to determine the effect of treatment on the observed parameters. If the results show that $\mathrm{F}$ arithmetic $>\mathrm{F}$ table $5 \%$ (4.07) and $>\mathrm{F}_{\text {table }} 1 \%$ (7.59) then $\mathrm{H}_{0}$ rejected and $\mathrm{H}_{1}$ accepted (Hanafiah, 2008).

\section{RESULT AND DISCUSSION}

The results of BOD and COD value in liquid coffee waste before treatment were 12 ppm and $35 \mathrm{ppm}$. While the results of the analysis of BOD and COD value after the experiment on day 3 can be seen in tables 1 and 2 .

Table 1. BOD value

\begin{tabular}{|c|c|c|c|c|c|c|}
\hline \multirow{2}{*}{$\begin{array}{l}\text { Tre } \\
\text { atm } \\
\text { ent }\end{array}$} & \multirow{2}{*}{$\begin{array}{l}\text { Quality } \\
\text { standard } \\
* \\
\text { ppm }\end{array}$} & \multicolumn{3}{|c|}{ Repeat } & \multirow{2}{*}{$\begin{array}{l}\text { Avera } \\
\text { ge }\end{array}$} & \multirow{2}{*}{$\begin{array}{c}\% \\
\text { Decre } \\
\text { ase }\end{array}$} \\
\hline & & 1 & 2 & 3 & & \\
\hline P0 & \multirow{4}{*}{3} & 6,7 & 15 & 16 & 12,57 & 0 \\
\hline P1 & & 5,9 & 9,5 & 11 & 8,8 & 30 \\
\hline $\mathrm{P} 2$ & & 1,9 & 6,8 & 9,8 & 6,17 & 51 \\
\hline P3 & & 2 & 3 & 5,5 & 3,5 & 72 \\
\hline
\end{tabular}

*PP RI No. 82 / 2001

Table 2. COD value

\begin{tabular}{|c|c|c|c|c|c|c|}
\hline \multirow{2}{*}{$\begin{array}{l}\text { Tre } \\
\text { atm } \\
\text { ent }\end{array}$} & \multirow{2}{*}{$\begin{array}{l}\text { Quality } \\
\text { standard } \\
* \\
\text { ppm }\end{array}$} & \multicolumn{3}{|c|}{ Repeat } & \multirow[t]{2}{*}{$\begin{array}{c}\text { Avera } \\
\text { ge }\end{array}$} & \multirow{2}{*}{$\begin{array}{c}\% \\
\text { Decre } \\
\text { ase }\end{array}$} \\
\hline & & 1 & 2 & 3 & & \\
\hline P0 & \multirow{4}{*}{25} & 19 & 44 & 47 & 36,67 & 0 \\
\hline $\mathrm{P} 1$ & & 16 & 28 & 34 & 26 & 29 \\
\hline $\mathrm{P} 2$ & & 6 & 19 & 28 & 17,67 & 52 \\
\hline P3 & & 6 & 9,5 & 16 & 10,50 & 71 \\
\hline
\end{tabular}

*PP RI No. 82 / 2001

Based on table 1, lotus phytoremediation on day 3 showed that the percentage reduction in BOD value in each treatment of $0 \mathrm{~g}, 25 \mathrm{~g}, 50 \mathrm{~g}$, and $75 \mathrm{~g}$ was $0 \%, 30 \%, 51 \%$, and $72 \%$. While table 2 shows the percentage reduction in COD value in each treatment is $0 \%, 29 \%, 52 \%$, and $71 \%$. Statistical analysis based on homogeneity test can be seen in table 3 
Table 3. BOD and COD homogeneity

\begin{tabular}{ccccc}
\hline & $\begin{array}{c}\text { Levene } \\
\text { Statistic }\end{array}$ & df1 & df & Sig. \\
\hline BOD & 1.737 & 3 & 8 & .237 \\
\hline COD & 1.632 & 3 & 8 & .258 \\
\hline
\end{tabular}

Based on Table 3, sig > 0.05, which means the treatment has a homogeneous variance. Then a further test of variance analysis was carried out which obtained the results of $\mathrm{F}$ count $>\mathrm{F}$ table $5 \%$ (4.07) and $>\mathrm{F}$ table $1 \%$ (7.59). So, these results indicate that $\mathrm{H}_{0}$ is rejected and $\mathrm{H}_{1}$ is accepted which states that lotus is effectively used as phytoremediation of liquid coffee waste. The effectiveness of reducing BOD and COD value by using lotus plants can be seen in Figure 1.

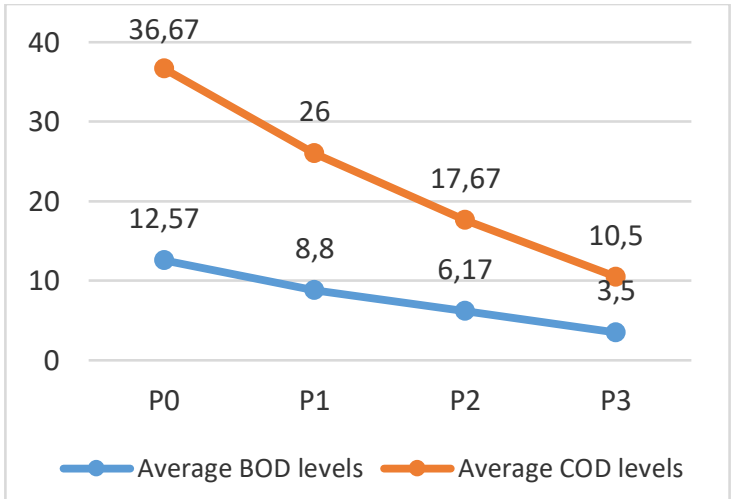

Figure 1. Decrease in BOD and COD value

The effectiveness of reducing BOD and COD value using lotus in Figure 1, there is a significant difference in the average decrease in BOD and COD value in liquid coffee waste with variations in plant biomass. The largest average decrease was at $\mathrm{P} 3$ with a lotus plant biomass of 75 grams showing an average decrease in BOD and COD of $3.5 \mathrm{ppm}$ and $10.5 \mathrm{ppm}$. So that lotus is effectively used as a phytoremediation agent for coffee liquid waste, which is indicated by the more lotus plant biomass, the greater the decrease in BOD and COD value of liquid coffee waste.

These results indicate that lotus is able to carry out a phytoremediation mechanism to reduce BOD value of liquid coffee waste on day 3. The results showed that BOD value decreased with increasing weight of biomass between treatments. The more phytoremediator plants, the more organic matter will be absorbed and the less organic matter that must be degraded by microorganisms. The less organic matter that must be degraded by microorganisms, the higher the oxygen content in wastewater (Muhajir, 2013).

The lotus plant is also able to carry out a phytoremediation mechanism to reduce the COD value of liquid coffee waste on the $3 \mathrm{rd}$ day. The more plant biomass, the higher the effectiveness of plants in reducing COD value of liquid coffee waste. The decrease in COD value in each treatment was caused by the fact that the solids had begun to settle so that the waste material from the liquid coffee waste was also reduced. In addition, some of the waste material has been oxidized and some has also been absorbed by plants so that it can reduce the COD value (Soemirat, 2009).

The decrease in BOD and COD value in liquid coffee waste using the phytoremediation method using lotus plants occurs because there is a process of absorption of organic matter by plants, especially by roots. Lotus plants have very thick and long roots so that they can expand the absorption area (Rukmi, 2014).

The phytoremediation mechanism of lotus in the absorption of organic matter begins with the stage Rhizofiltration, which is the process of deposition of contaminants in liquid coffee waste in the form of organic matter attached to the roots. After the pollutants penetrate the root endodermis, pollutants or other foreign compounds follow the transpiration flow through transport tissues (xylem and phloem) to other plant parts (Raras et al., 2015). The lotus plant absorbs pollutant substances through the roots then distributed to all parts of the plant, then contaminants in the form of organic substances that have complex molecular chains are broken down into harmless materials into simpler molecular arrangements that can be useful for the plant itself (phytodegradation), enzymes which plays a role in thestage phytodegradation is the enzyme oxygenase. The enzyme oxygenase functions in carrying out changes in the surrounding nutrients so as to allow 
these nutrients to enter cells (Nindra \& Hartini, 2015).

The decrease in organic matter in liquid coffee waste is also due to the lotus plant being classified as a hyperaccumulator plant because it has the ability to absorb heavy metals. The absorption and accumulation of heavy metals by plants can be divided into three processes, namely metal uptake by roots, metal translocation from roots to other plant parts, and metal localization in certain cell parts to prevent inhibition of plant metabolism. The metal uptake must be in contact with the solution in the root area so that the plant can absorb it directly. After the root cells have received the metal, then the metal is transported through the tissue's xylem and phloem to other plant parts. The chelate molecules are used to bind the metal, so that its transport efficiency can be increased. This molecule has several types and each type serves to bind metals. Localized tissue serves to prevent toxins from metal to cells. Hyperaccumulator plants also have detoxification mechanisms, for example by accumulating metals to certain roots and latex (Irhamni, 2020).

The decrease in BOD and COD value is in line with the increase in dissolved oxygen in liquid coffee waste. Prior to phytoremediation, the dissolved oxygen content of liquid coffee waste was $2 \mathrm{mg} / \mathrm{l}$. On the last day of lotus phytoremediation, dissolved oxygen levels in liquid coffee waste increased to $4 \mathrm{mg} / \mathrm{l}$. This is because the source of dissolved oxygen can come from the photosynthetic activity of aquatic plants. The existence of lotus plants supports the fulfillment of dissolved oxygen needs in liquid coffee waste, namely by high photosynthetic activity which will result in higher dissolved oxygen in wastewater (Ningsih, 2017). In addition, the release of oxygen by the roots of aquatic plants causes the media around the root hairs to have higher dissolved oxygen, making it possible to become a micro-habitat for aerobic microorganisms to decompose organic matter (Suprihatin, 2014).

The phytoremediation process is influenced by environmental conditions such as temperature and $\mathrm{pH}$. The state of $\mathrm{pH}$ based on measurements obtained that the initial $\mathrm{pH}$ of the coffee liquid waste was 9 (alkaline) and the $\mathrm{pH}$ decreased to an average $\mathrm{pH}$ of 6-7 (neutral). Meanwhile, the average temperature of liquid coffee waste at the time of treatment was $25^{\circ} \mathrm{C}-26^{\circ} \mathrm{C}$. The temperature of the liquid coffee waste was influenced by the ambient temperature due to the weather during treatment. The optimal temperature for lotus growth ranges from 21 ${ }^{\circ} \mathrm{C}-24{ }^{\circ} \mathrm{C}$, and a good $\mathrm{pH}$ for optimal lotus growth ranges from 4 - 6. Temperature affects the absorption rate because temperature is related to metabolic and photosynthetic processes. (Karnain, 2016). Morphological observations were seen in the physical condition of lotus plants during the treatment. On the 6 days of phytoremediation, the plants began to show symptoms of chlorosis, namely the leaves changed their color from green to yellow. Chlorosis can occur due to the absorption of excess organic matter (Rukmi, 2014).

\section{CONCLUSION}

From the results of the study, it can be concluded as follows:

1. The lotus plant is effective as a phytoremediation agent to reduce BOD value of liquid coffee waste in lotus biomass 75 grams with a decrease of $72 \%$.

2. The lotus plant is effective as a phytoremediation agent to reduce COD value of liquid coffee waste in lotus biomass 75 grams with a decrease of $71 \%$.

\section{REFERENCES}

Andyanto, N., Kaswinarni, F., \& Rahayu, P. (2019). Kemampuan Tanaman Nymphaea pubescens Dalam Menurunkan Kadar Fosfat dan Amonia Pada Limbah Cair Rumah Tangga. Prosiding Seminar Edusaintek. Semarang: Program Studi Pendidikan IPA S1 FMIPA UNIMUS.

Atima, W. (2015). BOD dan COD Sebagai Parameter Pencemaran Air dan Baku Mutu Air Limbah. Jurnal Biology Science \& Education, 4(1), 99-111.

Hanafiah, K. A. (2008). Rancangan Percobaan Aplikatif. Aplikasi Kondisional Bidang Pertamanan, 
peternakan, Perikanan, industri, dan Hayati. Jakarta: PT. Raja Grafindo Persada.

Irhamni. (2020). Efektifitas Tumbuhan Air Dalam Menyerap Logam Berat $(\mathrm{Cr}$, $\mathrm{Hg}, \mathrm{Pb}$ ) secara Fitoremediasi Pada Lindi Tempat Pembuangan Akhir Kota Banda Aceh (Doctoral dissertation). Program Pascasarjana Universitas Sumatera Utara, Medan.

Karnain, Ramadhiantie. (2016). Hubungan Evaporasi Terhadap Pertumbuhan Tanaman Teratai Putih (Nymphaea alba). Skripsi. Universitas Sumatera Utara.

Khaer, A., \& Nursyafitri, E. (2019). Kemampuan Metode Kombinasi Filtrasi Fitoremediasi Tanaman Teratai Dan Eceng Gondok Dalam Menurunkan Kadar BOD Dan COD Air Limbah Industri Tahu. Sulolipu: Media Komunikasi Sivitas Akademika Dan Masyarakat, 17(2), 11.

Mahyatun, W. O., Samang, L., \& Zubair, A. (2014). Fitoremediasi Logam Cd Menggunakan Kombinasi Eceng Gondok dan Kayu Apu dengan Aliran Kontinyu. Repository Universitas Hasanuddin, 1-12.

Manik, K.S.E. (2016). Pengelolaan Lingkungan Hidup. Jakarta: Prenamedia Group.

Muhajir, M. S. (2013). Penurunan Limbah Cair BOD dan COD pada Industri tahu Menggunakan Tanaman Cattail (Typha agustifolia) dengan Sistem Constructed Wetland. Skripsi. Universitas Negeri Semarang.

Nindra, D. Y., \& Hartini, E. (2015). Efektivitas Anaman Teratai (Nympahea firecrest) dan Eceng Gondok (Eichhornia crassipes) Dalam Menurunkan Kadar Biochemical Oxygen Demand) Pada Limbah Cair Industri Tahu. VISIKES: Jurnal Kesehatan Masyarakat, 14(2), 123130.

Ningsih, D. A. (2017). Uji Penurunan Kandungan BOD, COD, dan warna Pada Limbah Cair Pewarnaan Batik Menggunakan Scirpus grossus dan Iris pseudacorus dengan Sistem
Pemaparan Intermittent. Skripsi. Institut Teknologi Sepeluh November.

Raras, D. P., Yusuf, B., Kalimantan, M., \& Dalam, T. (2015). Analisis Kandungan Ion Logam Berat ( $\mathrm{Fe}, \mathrm{Cd}, \mathrm{Cu}$ dan $\mathrm{Pb}$ ) pada Tanaman Apu-Apu ( Pistia Stratiotes L ) dengan Menggunakan Variasi Waktu. Prosiding Seminar FMIPA. Universitas Mulawarman.

Rukmawati, B. S. (2015). Perbaikan Kualitas Limbah Cair Pengolahan Kopi Menggunakan Sirkulasi Pada Proses Fitoremediasi. Skripsi. Universitas Jember.

Rukmi, D. P. (2014). Efektivitas Eceng Gondok (Eichhornia crassipes) Dalam Menurunkan Kadar Deterjen, BOD, dan COD Pada Air Limbah Laundry. Skripsi. Universitas Jember.

Sariadi. (2011). Pengolahan Limbah Cair Kopi dengan Metode Elektrokoagulasi secara Batch. Jurnal Teknik Kimia, 7276.

Soemirat, Slamet. (2009). Kesehatan Lingkungan. Yogyakarta: Gadjah Mada University Press.

Suprihatin, H. (2014). Kandungan Organik Limbah Cair Industri Batik Jetis Sidoarjo dan Alternatif Pengolahannya. Skripsi. Institut Teknologi Pembangunan Surabaya. 